\title{
The degradation of linuron in sandy soil
}

\author{
HELVI HEINONEN-TANSKI \\ Department of Environmental Engineering, University of Kuopio, POB 6, \\ SF-70211 Kuopio, Finland
}

\begin{abstract}
The degradation of linuron occurs both in aerobic and anaerobic sandy soil with a slight lag when the conditions change from aerobic to anaerobic or from anaerobic to aerobic. Liming was found to stimulate the degradation rate of linuron so clearly that liming can be recommended for acceleration of linuron degradation as a normal agricultural treatment, particularly in sandy soils.
\end{abstract}

Index words: Liming, degradation acceleration, herbicide, ${ }^{14} \mathrm{C}$-linuron, flow-through system.

\section{Introduction}

Linuron (3,4-dichlorophenyl-1-methyl-1methoxyurea) has been used in many countries as a pre-emergency or post-emergency herbicide in the cultivation carrot and some other plants.

The disappearance of linuron from soil occurs mainly by microbial cometabolic degradation (Glad et al. 1981; WALKer \& ZiMDAHL 1981; STEPP et al. 1985; WANG et al. 1985).

The mobility of linuron is very low because of its high tendency to adsorb with soil particles and organic compounds as determined by the adsorption constants of GLAD et al. (1980) and WALKer (1987). Most linuron residues can be found in the soil layer of 0 $6 \mathrm{~cm}$ (Walker 1987). Thus Zahnow and Riggleman (1980) did not find linuron in the mud or water of a North American bay despite the great amounts of linuron used on the fields near this bay and its tributaries. In one case (FrAnK et al. 1987), linuron was found in farm well water, but in this case it was assumed that linuron was in the water because of spills while mixing and loading the spray equipments near the wells.

Linuron forms complex compounds with humic acids (SENESI 1981) as well as some of its potential degradation products (SAXENA \& BARTHA 1983 and BARTHA et al. 1983).

The microbial degradation of linuron can begin either by dechlorination or by side chain degradation. STEPP et al. (1985) found the reductive dechlorination of para-chlorine to occur in anaerobic pond sediment. The 
side chain degradations (demethylation, demethoxylation and hydrolysis of amide bound) have been known for a long time (BÖRNER, 1965), and at least in aerobic soil they may be more important. When ${ }^{14} \mathrm{C}$ labelled linuron degraded in soil, the amount of ${ }^{14} \mathrm{C}$-carbonyl-labelled demethylated and demethoxylated degradation products in soil was only $5 \%$ that of the undegraded ${ }^{14} \mathrm{C}$-carbonyl-labelled linuron (WALKER 1976), but the formation of ${ }^{14}$ carbon dioxide was a good indicator of the total degradation of linuron. Thus it can be assumed that hydrolysis of the amide bound following by decarboxylation is the most important degradation way of linuron, the main metabolite being 3,4-dichloroaniline.

Linuron has been found to degrade in some soils quite rapidly (KLEMPSON-JONES \& HANCE 1979; WALKER 1976 and 1987) or in some other soils very slowly (GLAD et al., 1980; WALKER \& ZimDAHL 1981). The degradation rate depends on temperature, soil moisture and $\mathrm{pH}$. The degradation rate was higher at $22^{\circ} \mathrm{C}$ than at $10^{\circ} \mathrm{C}$ and the rate was higher when the moisture was neither too high nor too low (Klempson-Jones \& Hance 1979). A pH-value above pH 6 seems to be more favourable than lower pH-values (HANCE 1979). The very slow degradation of linuron has in some cases damaged the next yields (Eagle 1981; Heinoneiv TAnski et al. 1986), or the soil residue levels can be critically high if the weather is unfavourable (MUNDELL \& OlAFSSON 1982).

Thus, there is a great need for methods to accelerate the degradation of linuron in practical agriculture. This need may be greatest in the Nordic climate after cold and short summers, such as summer 1987 , or after very dry or very rainy summers. The cometabolic degradation could be accelerated by addition to soil substrates, which increase the microbial activity of soil. In practice, such compounds could be organic or inorganic fertilizers or lime. Doyle et al. (1978) found that dairy manure and sewage sludge increased the degradation rate of linuron. Liming may generally increase microbial activity in easily acidified Finnish soils. Therefore it was selected for this experiment as a possible accelerator for the degradation of linuron.

\section{Materials and methods}

Soil: Carrot was cultivated in sandy soil in Laukaa, Central Finland $\left(62^{\circ} 28^{\prime} \mathrm{N}\right.$ and $25^{\circ} 56^{\prime} \mathrm{E}$ ), weeds were controlled annually for seven years by two sprayings of $1.8 \mathrm{~kg} / \mathrm{ha}$, and then for four years by one spraying of $1.8 \mathrm{~kg} / \mathrm{ha}$ linuron (as Afalon). The plots were then limed with dolomitic lime $(0,5$ or $10 \mathrm{t} / \mathrm{ha}$ ) in May before the last seeding and linuron application. Soil samples were taken in autumn five months after the liming, when harvesting the eleventh carrot yield. The organic matter of soil was $2.6 \%$ and mechanical analysis gave the following percentages: medium coarse sand $3.0 \%$, fine sand $35 \%$, very fine sand $25 \%$, silt $26 \%$, and clay $11 \%$. This soil had earlier contained up to $0.4-$ $0.5 \mathrm{mg} / \mathrm{kg}$ linuron one year after the last linuron application (HEINONEN-TANSKI et al. 1986). The other properties of autumn samples are presented in Table 1.

Laboratory tests: Soil samples were airdried at room temperature and added to a flow-through system bottles (Goswami \& Kосн 1976). ${ }^{14} \mathrm{C}$-carbonyl linuron (Hungarian Academy of Sciences, Institute of Isotopes, Budapest) and unlabelled linuron (Hoechst) were applied to $1 \mathrm{mg} / \mathrm{kg}$. The field capacity of the soil was adjusted to $60 \%$ with tap water

Table 1. The chemical analyses of the soils five months after liming (unlimed control, limed with $5 \mathrm{t} / \mathrm{ha}$ and $10 \mathrm{t} / \mathrm{ha})$.

\begin{tabular}{lccc}
\hline & Unlimed & $\begin{array}{c}\text { Limed } \\
5 \mathrm{t} / \mathrm{ha}\end{array}$ & $\begin{array}{c}\text { Limed } \\
10 \mathrm{t} / \mathrm{ha}\end{array}$ \\
\hline $\mathrm{pH}_{\mathrm{KCa}}$ & 6.2 & 6.7 & 6.7 \\
$\begin{array}{l}\text { Conductivity } \\
\mu \mathrm{S} 10^{2} / \mathrm{cm}\end{array}$ & 0.45 & 0.54 & 0.81 \\
$\mathrm{Ca} \mathrm{mg/1}$ & 875 & 1175 & 1975 \\
$\mathrm{~K} \mathrm{mg/l}$ & 105 & 100 & 95 \\
$\mathrm{Mg} \mathrm{mg/1}$ & 120 & 150 & 210 \\
\hline
\end{tabular}


and the temperature was set at $15^{\circ} \mathrm{C}$. The soils were watered when the field capacity had decreased $30-40 \%$, which is too low for optimal microbial activity and linuron degradation. Radioactive carbon dioxide was trapped with ethanolamine and measured with a scintillation counter (Lignell et al. 1984). The trapping capacity was tested with $\mathrm{Na}^{14} \mathrm{CO}_{3}$ and $\mathrm{HCl}$, and it was better than $95 \%$. The flow-through gas was synthetic air $\left(80 \% \mathrm{~N}_{2}\right.$ and $20 \% \mathrm{O}_{2}$ ) until the 164th day, then nitrogen until the 234th day, and air again until the end of the experiment on the 252th day.

After the flow-through system experiment, the soil $(1.25 \mathrm{~g})$ was extracted three times with water to separate the water-soluble metabolites. After the water extraction, linuron and related aromatics in the soil were extracted for 8 hours in a Soxhlet apparatus with acetone. The humins were then separated from the soil by extraction with $0.5 \mathrm{~N} \mathrm{NaOH}$ solution, first overnight and then twice for 2 hours, and by centrifugation for $30 \mathrm{~min}$ at $10000 \mathrm{rpm}$. The humins were found in vacuum-dried precipitant. The supernatant was acidified with concentrated $\mathrm{HCl}$ to $\mathrm{pH} 1.0$ and centrifuged again as above. The $\mathrm{HCl}$-supernatant contains then fulvic acids and $\mathrm{HCl}$-precipitant humic acids. The separation was based on the method described by HÄNNINEN et al. (1981). The radioactivities of soil extractions were measured by using $1.5 \mathrm{ml}$ of sample solution or water and $10 \mathrm{ml}$ of scintillator cocktail (University Pharmacy, Helsinki YA-gel). The total radioactivity of the soil was combusted in a sample oxidizer, trapped and counted as described by Lignell et al. (1984).

\section{Results}

The cumulative evolution of ${ }^{14} \mathrm{CO}_{2}$ from ${ }^{14} \mathrm{C}$-linuron during the incubation is shown in Fig. 1. In limed plots the degradation of linuron was clearly accelerated. This acceleration was statistically significantly higher in the two limed plots as compared to the unlimed plots, both in the first sampling (limed $5 \mathrm{t} / \mathrm{ha}$ ) or after one week (limed $10 \mathrm{t} / \mathrm{ha}$ ).

The degradation rate was practically the same in both soils limed with either 5 or

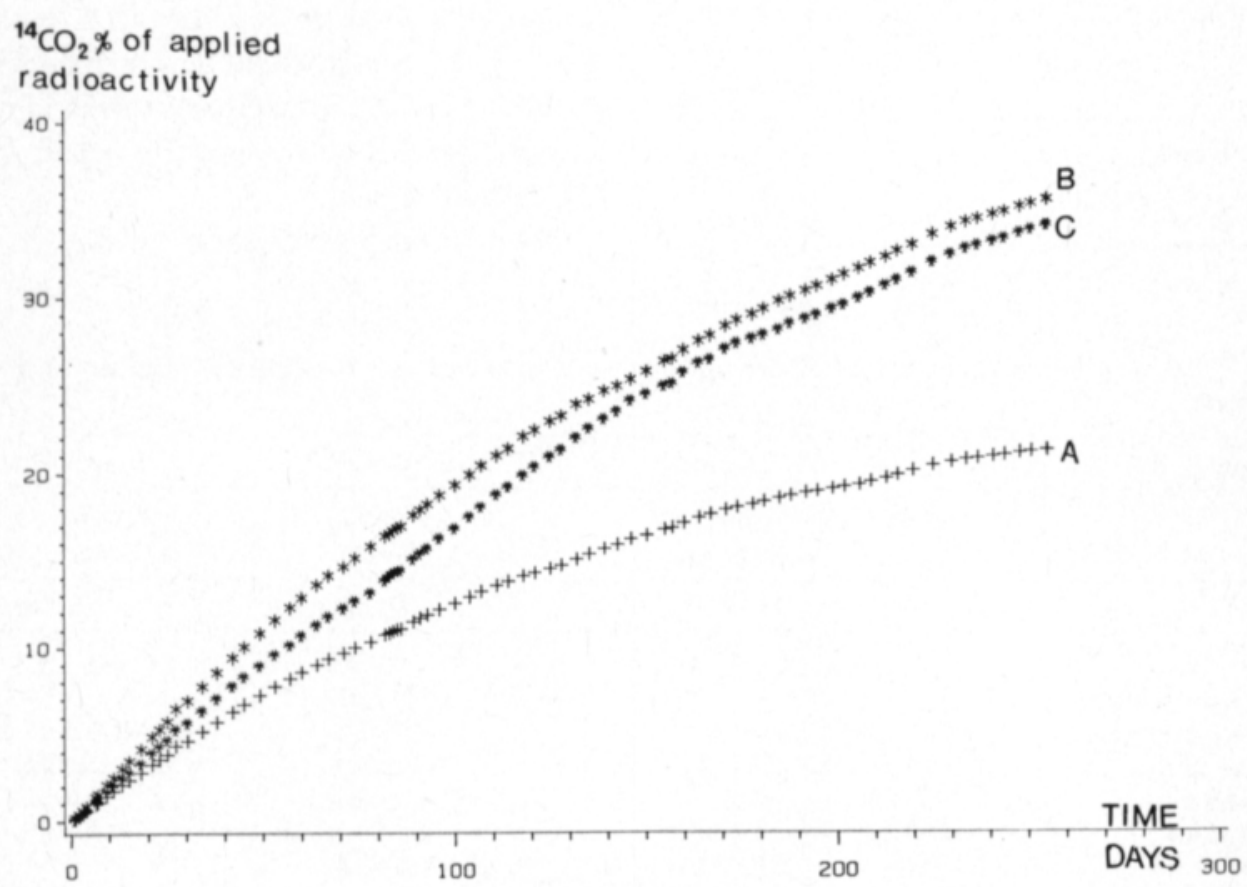

Fig. 1. The evolution of ${ }^{14} \mathrm{CO}_{2}$ in flow-through systems. $\mathrm{A}=$ unlimed, $\mathrm{B}=\operatorname{limed} 5 \mathrm{t} /$ ha and $\mathrm{C}=\operatorname{limed} 10 \mathrm{t} / \mathrm{ha}$. 
$10 \mathrm{tn} / \mathrm{ha}$, and there was no statistically significant difference.

The initial degradation rate was highest, but after $1-2$ weeks the degradation rate was more stable. The main rates per day are presented in Table 2 . When air was substituted for nitrogen, the degradation rate first decreased, but it increased again gradually without ever reaching the degradation rates before incubation with nitrogen as the flow-through gas. Again, when nitrogen was substituted for air, the degradation rates first decreased and then increased.

The distribution of ${ }^{14} \mathrm{C}$-activity between $\mathrm{CO}_{2}$ and different soil fractions after 252 days' of incubation is shown in Table 3.

\section{Discussion}

In this experiment, the degradation of linuron was much slower than presented by

Table 2. The degradation rate per day in unlimed and limed soils ( $5 \mathrm{t} / \mathrm{ha}$ and $10 \mathrm{t} / \mathrm{ha}$ ) using a flow-through gas air or nitrogen.

\begin{tabular}{lccc}
\hline $\begin{array}{l}\text { Flow-through } \\
\text { gas phase }\end{array}$ & \multicolumn{3}{c}{$\begin{array}{l}\text { Degradation rate of linuron } \% / \\
\text { day of initially added in soils. }\end{array}$} \\
\cline { 2 - 4 } & Unlimed & $\begin{array}{c}\text { Limed } \\
5 \mathrm{t} / \mathrm{ha}\end{array}$ & $\begin{array}{c}\text { Limed } \\
10 \mathrm{t} / \mathrm{ha}\end{array}$ \\
\hline Air before $\mathrm{N}_{2}$ & 0.10 & 0.17 & 0.16 \\
31 days with $\mathrm{N}_{2}$ & 0.05 & 0.11 & 0.10 \\
Air after $\mathrm{N}_{2}$ & 0.03 & 0.06 & 0.06 \\
\hline
\end{tabular}

Hance (1979), Maier-Bode and Härtel (1981) and WALKer (1987). The half-life would be more than eight months, calculated from the formation of ${ }^{14} \mathrm{CO}_{2}$. At the same time, half or almost half of the radioactivity added as linuron was still found in soil, most of it in acetone extract (and possible partly in water, too) in the form of linuron.

The binding of linuron or its metabolites to humus was less than $15 \%$ of the linuron added. The possible binding of 3,4-dichloroaniline, an important metabolite of linuron known to bind to humus (BARTHA et al. 1983) is not included in this figure because this aniline derivate would not be radioactive.

The changes from aerobic to anaerobic and from anaerobic to aerobic initially caused a microbial lag, which might be more important in natural soils with dry and rainy periods.

Lime accelerates the degradation of linuron so clearly that liming could be recommended in acid soils, for instance, after spills or accidental overdoses of linuron or if linuron has been used for many years in the same plot, or perhaps after unfavourable growing seasons (cold, short, very rainy or very dry), like summer 1987 in Northern Europe. After such growing seasons, it would be worth performing liming earlier, which is a normal and regular operation in Nordic agricultural soils lacking calcium buffer.

Organic fertilizers, such as manure or

Table 3. The distribution percentage of ${ }^{14} \mathrm{C}$-activity in unlimed and limed soils after 252 days. (Mean \pm standard deviation).

\begin{tabular}{lccc}
\hline Fraction & Unlimed & Limed 5 t/ha & Limed $10 \mathrm{t} / \mathrm{ha}$ \\
\hline${ }^{14} \mathrm{CO}_{2}$ & $21.0 \pm 2.0$ & $35.1 \pm 3.3$ & $33.7 \pm 5.1$ \\
In soil & $54.7 \pm 11.1$ & $37.0 \pm 7.4$ & $40.9 \pm 13.4$ \\
\hline Recovery & $75.7 \pm 12.0$ & $72.1 \pm 8.4$ & $76.6 \pm 14.3$ \\
\hline In soil: & & & $6.6 \pm 2.9$ \\
Water soluble compounds & $9.1 \pm 2.0$ & $4.3 \pm 1.5$ & $23.0 \pm 5.1$ \\
(maybe partly linuron) & $20.7 \pm 7.7$ & $20.5 \pm 4.4$ & $5.3 \pm 1.5$ \\
Acetone extract (linuron ect.) & $6.8 \pm 6.1$ & $6.6 \pm 2.3$ & $0.3 \pm 0.1$ \\
Fulvic acids & $0.3 \pm 0.1$ & $0.6 \pm 0.3$ & $2.5 \pm 1.2$ \\
Humic acids & $7.6 \pm 5.8$ & $5.4 \pm 3.6$ & $37.7 \pm 6.2$ \\
\hline Humins & $44.5 \pm 11.6$ & $37.4 \pm 6.3$ & \\
\hline Sum in soil found & & \\
\hline
\end{tabular}


sludge which Doyle et al. (1978) found to accelerate the degradation of linuron, would also be worth trying.

The results presented in Table 3 show the fate of only $75-80 \%$ of linuron. A leakage in the flow-through system would easily explain this lack but it is not a probable explanation because the parallel results were too close to each other. There is always some leakage during the sampling of ${ }^{14} \mathrm{CO}_{2}$ results, which occurred 85 times during this experiment, each time taking approximately 30 secs. In addition to the weighing and changing of gas bottles, watering also caused some leakage. Watering was done approximately 10 times, each time taking 10-15 minutes. As the entire experiment took 252 days, these er- rors may have some importance. It is also possible that the original application of linuron solution in $100 \mu \mathrm{l}$ had an error of up to 10 $15 \%$.

Acknowledgements. I am grateful for Dr. Eva Eklund for her critical comments. I thank Mr. Paavo Simojoki, M. Sc. (Agr.) of the Central Finland Experimental Station, for all his field works during these years and for the soil samples and Mr. Antti Uusi-Rauva, M. Sc. of the University of Helsinki, Instrument Centre, Faculty of Agriculture and Forestry, where the ${ }^{14} \mathrm{CO}_{2}$-evalutions were done. I would like to express my appreciation to both of them for their long collaboratorion. Miss Arja Hälinen has done the fractionation of linuron metabolites with great accurancy, and Mr. Hannu Eskelinen, M. Sc. has done the computer work. Mr. Kari Puukko, M. Sc. (Agr.) from Hoechst Fennica is thanked for providing linuron. Mrs. Sevastiana Ruusamo M. A. has corrected the English language.

\section{References}

Bartha, R., You; I.-S. \& Saxena, A. 1983. Humusbound residues of phenylamide herbicides: Their nature, persistence and monitoring. IUPAC Pesticide Chemistry. Ed. J. Miyamoto et al. Pergamon Press, Oxford, pp. 345-350.

Borner, H. 1965. Untersuchungen über den Abbau von Afalon (N-(3,4-Dichlorphenyl)-N'-methoxy-N'methylharnstoff) und Aresin (N-(4-Chlorphenyl)N'-methoxy-N'-methylharnstoff) im Boden. Zeitschr. Pflkranh. Pflsch. 72: 516-531.

Doyle, R.C., Kaufman, D.D. \& Burt, G.W. 1978. Effect of dairy manure and sewage sludge on ${ }^{14} \mathrm{C}$ pesticide degradation in soil. J. Agric. Food Chem. 26: $987-989$.

EAGLE, D.J. 1981. Residue problems encountered in England. Proc. EWRS Symp. Theory Pract. Use Soil Applied Herbicides pp. 201-207.

Frank, R., Dipley, B.D., Braun, H.E., Clegg, B.S., Johnston, R. \& O'Neill, T.J. 1987. Survey of farm wells for pesticide residues, Southern Ontario, Canada, 1981-1982, 1984. Arch. Environ. Contam. Toxicol. 16: 1-8.

Glad, G., Goransson, B., Popoff, T., Theander, O. \& Torstensson, N.T.L. 1981. Decomposition of linuron by fungi isolated from soil. Swed. J. Agric. Res. 11: $127-134$.

-, Nilsson, H., Popoff, T., Theander, O. \& Torstens. SON, N.T.L. 1980. Performance of linuron in four Swedish soil types. Swed. J. Agric. Res. 10: 133-137.

Goswamı, K.P. \& Косн, B.L. 1976. A simple apparatus for measuring degradation of ${ }^{14} \mathrm{C}$-labelled pesticides

in soil. Soil Biol. Biochem. 8: 527-528.

HANCE, R.J. 1979. Effect of $\mathrm{pH}$ on the degradation of atrazine, chlorprop, linuron and propyzamide in soil. Pestic. Sci. 10: 83-86.

Hänninen, K., Lehto, O. \& Mäl-Könen, P. 1981. Identification of phenolic acids, molecular weight determinations of fulvic acids and quantitative measurements of phenolic and fulvic acids by HPLC from forest and moss humus. Proc. Intern. Peat Symposium, Bemidji, Minnesota, pp. 117-155.

Heinonen-Tanski, H., Siltanen, H., Killpi, S., Simojoki, P., Rosenberg, C. \& Mákinen, S. 1986. The effect of the annual use of some pesticides on soil microorganisms, pesticide residues in soil and carrot yields. Pestic. Sci. 17: 135-142.

Klempson-Jones, G.F. \& Hance, R.J. 1979. Kinetics of linuron and metribuzin degradation in soil. Pestic. Sci. 10: $449-454$.

Lignell, R., Heinonen-Tanski, H. \& Uusi-Rauva, A. 1984. Degradation of trichloroacetic acid (TCA) in soil. Acta Agric. Scand. 34: 3-8.

Maier-Bode, H. \& Härtel, K. 1981. Linuron and monolinuron. Residue Rev. 77: 1-152.

Mundell, D. \& Olafsson, S. 1982. Residue of linuron in soils and potatoes in Iceland. Isl. Landbun. J. Agric. Res. Icel. 14: 3-17.

SAXena, A. \& Bartha, R. 1983. Modelling of the covalent attachment of chloroaniline residues to quinoidal sites of soil humus. Bull. Environ. Contam. Toxicol. 30: $485-491$.

SENESI, N. 1981. Free radicals in electron donor-accep- 
tor reactions between a soil humic acid and photolysis inhibitor herbicides. Z. Pflanzenernähr. Bodenk. 144: $580-586$.

Stepp, T.D., Camper, N.D. \& Paynter, M.J.B. 1985. Anaerobic microbial degradation of selected 3,4-dihalogenated aromatic compounds. Pestic. Biochem. Physiol. 23: 256-260.

WALKER, A. 1976. Simulation of herbicide persistence in soil. II Simazine and linuron in long-term experiments. Pestic. Sci. 7: 50-58.

- 1987. Evaluation of a simulation model for prediction of herbicide movement and persistence in soil. Weed Res. 27: 143-152.

\section{SELOSTUS}

\section{Linuronin hajoaminen hietamaassa}

\section{Helvi Heinonen-Tanski}

\author{
Kuopion yliopisto, \\ Teknisen ympäristöhygienian laitos, \\ Pl 6, 70211 Kuopio
}

Linuronia on käytetty meillä lähinnä porkkanan viljelyssä herbisidinä joko ennen tai jälkeen taimettumisen. Karuissa maissa sekä epäedullisissa sãäoloissa (liian kuivaa, liian sateista tai liian lyhyt tai liian kylmä kasvukausi) linuron ei ehdi hajota riittävän täydellisesti ja jäämävaara maan pintakerroksissa on olemassa. Jaămăriski lisaaăntyy myös, jos samaa maata kăsitelläăn toistuvasti tai linuronia kảytetaaăn ylisuurina annoksina. Pahimmillaan linuronjäämät ovat alentaneet seuraavan samassa lohkossa viljeltävăn kasvin kasvua ja satoa, mistä on olemassa kirjallisuudessa esimerkkejä.

Tässă työssă on tutkittu keinoja nopeuttaa linuronin hajoamista maassa. Linuron on lisätty ${ }^{14} \mathrm{C}$-leimattuna suomalaiseen karkeaan ja melko happamaan hietamaahan.

Osa maista oli kalkittu (5 tn tai $10 \mathrm{tn} / \mathrm{ha}$ ) edellisenă keväănä, viisi kuukautta ennen maanäytteiden ottoa. Maan alkuperäinen $\mathrm{pH}$ oli $\mathrm{pH} 6,2$ ja kalkituksen jälkeen
— \& ZıMDAhL, R.L. 1981. Simulation of the persistence of atrazine, linuron and metolachlor in soil at different sites in the USA. Weed Res. 21: 255-265.

Wang, Y.-S., Madsen, E.L. \& Alexander, M. 1985. Microbial degradation by mineralization or cometabolism determined by chemical concentration and environment. J. Agric. Food Chem. 33: 495-499.

Zahnow, E.W. \& Riggleman, J.D. 1980. Search for linuron residues in tributaries of the Chesapeake Bay. J. Agric. Food Chem. 28: 974-978.

Ms received February 5, 1988 se oli pH 6,7 kummassakin kalkitussa maassa. Seurattiin ${ }^{14} \mathrm{CO}_{2}$ :n vapautumista $15^{\circ} \mathrm{C}$ :ssa 252 pảivän ajan. Kalkitus lisăsi erittăin selvästi linuronin hajoamista. Tässä kokeessa ei voitu havaita eroja eri kalkkimảärien vălillă.

Linuronin hajoaminen jatkui sekä aerobisissa ettả anaerobisissa olosuhteissa; tosin kun olosuhteita muutettiin aerobista anaerobisiksi ja päinvastoin, hajoamisnopeus aina aluksi hidastui, millă seikalla on varmasti merkitystă kesinä, joina runsassateiset ja kuivat jaksot vuorottelevat.

Tämăn kokeen perusteella linuronin puoliintumisaika olisi tutkitussa maassa noin $8 \mathrm{kk}$, mikă on selvästi pidempi kuin kirjallisuudessa tavallisesti esitetyt 2-4 kk.

Kokeen perusteella voidaan olettaa, että maan normaali ylläpitokalkitus nopeuttaa merkittävästi linuronin hajoamista ja tătä kalkitusta kannattaisi käyttảả hyvảksi jopa aikaistettuna, jos on syytă epäillä, että maahan on jäänyt liian korkeita linuronjäämiä. 